\title{
Uluslararası Çalışma Örgütü ve Enformasyon Sistemleri İnovasyonu
}

\section{International Labour Organization and Information Systems Innovation}

\author{
Volkan Hacıoğlu' ${ }^{1}$
}

\section{Öz}

Küreselleşme ve enformasyon teknolojileri ile hız kazanan iktisadî entegrasyon uluslararası piyasaların tanımını, yapısını ve sınırlarını değiştirmiştir. Endüstriyel organizasyonda sektörlerarası işbirliğinin artması, yeni talepler ve yeni toplumsal intiyaçlar karşısında çok uluslu örgütlerin hiyerarşik yapılanmalarında inovasyon temelli reformların gerçekleşmesine neden olmuştur. Endüstri 4.0 çağındaki küresel iktisadî sistemde ve stratejik rekabet ortamında genel bir otorite ve itibar sahibi olan Uluslararası Çalışma Örgütü de 10 Haziran 2008 tarihinde Cenova'da gerçekleştirilen Uluslararası İşgücü Konferansı'nda imzalanan Adil Küreselleşme için Sosyal Adalet Deklarasyonu ile İkinci Dünya Savaşı'ndan ve 10 Mayıs 1944 tarihli Philadelphia Deklarasyonu'ndan bu yana hedeflerinde ve normatif fonksiyonlarında ilk defa geniş çaplı bir yapısal reform hareketi başlatmıştır. Bu makalede, Uluslararası Çalışma Örgütü’nün inovasyon temelli reform planı analitik olarak değerlendirilmekte ve örgüt teorisi çerçevesi içinde fonksiyonları yeniden tanımlanmaktadır. Literatürde ilk defa tarafimızdan formüle edilen Örgütsel İnovasyon Fonksiyonu'nu Örgütsel İnovasyon Sistemi'ne entegre etmek suretiyle Uluslararası Çalışma Örgütü enformasyon sistemlerinin kapsamlı ve bütünlüklü bir teorik altyapısını kurmak amacıyla iki temel örgütsel inovasyon modeli incelenmektedir. Çalışmamızda, sonuç olarak, 21. yüzyılda Uluslararası Çalışma Örgütü’nün varlık nedeninin (raison d'être) iş̧̧i-işveren-hükümet üçlü yapısının yanısıra inovasyon temelli girişimcilik fonksiyonlarını da kapsayacak şekilde küresel dinamizm kazanarak genişlemiş ve gelişmiş olduğu ortaya konulmaktadır.

\section{Anahtar Kelimeler}

Örgütsel İnovasyon Sistemi, Örgütsel İnovasyon Fonksiyonu, Enformasyon Sistemleri İnovasyonu, Uluslararası Çalışma Örgütü Enformasyon Sistemleri

\begin{abstract}
The economic integration that has gained acceleration with globalization and information technologies changed the definition, structure and boundaries of international markets. Increasing intersectoral collaboration in industrial organization has caused the fulfilment of innovation based reforms in the hierarchical structure of multilateral organizations against new demands and social needs. The International
\end{abstract}

1 Sorumlu Yazar: Volkan Hacıoğlu (Dr. Öğr. Üyesi), İstanbul Üniversitesi, İktisat Fakültesi, İktisat Bölümü, İstanbul, Türkiye. E-posta: volkanh@istanbul.edu.tr ORCID: 0000-0003-2848-5399

Att: Hacioglu, V. (2019). Uluslararası çalışma örgütü ve enformasyon sistemleri inovasyonu. Sosyal Siyaset Konferansları Dergisi, 77: 97-130. https://doi.org/10.26650/jspc.2019.77.0012 
Labour Organization (ILO), which has a general authority and reputation in the global economic system and strategic competition environment of Industry 4.0 era, also initiated a large scale structural reform movement in its objectives and normative functions with the Declaration on Social Justice for a Fair Globalization singed in Genova on June 10, 2008 for the first time after the Philadelphia Declaration on May 10, 1944, and Second World War. In this article, we analytically evaluate the innovation based reform plan of ILO and redefine its function in the framework of the theory of organization. The two models of organizational innovation are examined in order to construct the comprehensive and complete theoretical infrastructure of ILO information systems to integrate the Organizational Innovation Function, formulated by us onto that of Organizational Innovation System. In our work, as a result, we show that the raison d'être of ILO has broadened and developed by gaining global dynamism to comprehend, not only the tripartism of governmentemployer-employee, but also innovation based entrepreneurial functions.

\section{Keywords}

Organizational Innovation System, Organizational Innovation Function, Information Systems Innovation, ILO Information Systems 


\section{Extended Summary}

The definition in comparison to scope and scale of market structure changes and broadens beyond the traditional conception of the neoclassical economic theory in an era of globalization. The extent of the market for goods and services integrates with digital economies and networks all around the world. Rapidly developing technology, together with ever changing economic and social structure, cause new trends to occur and continue unprecedentedly in the 21 th century. In line with the global and technological transformation of market structures and functions, the strategic significance of information is also increased within the decision making process of employees and employers, entrepreneurs and other economic agents. In today's business world, innovation based production projects of innovative entrepreneurs are particularly effective and decisive on the formation of expectations and demand dynamics.

In order to establish an equilibrium state for demand and supply of labour at the full employment level, the amount and cost of information in labour markets must be at an optimum level. In this sense, the foundation of the micro infrastructures of macroeconomic equilibrium state of the economy requires technology based innovation of information systems. The flow of information disseminates through the economy via economic institutions and organizations. Besides, networks beyond markets play an important part of the information transmission mechanism. The information systems innovation within the general structure of organizations in the economy minimizes Keynesian coordination failures, and thereby accelerates the restoration of equilibrium after a randomly external and fully anticipated economic shock which is a sole source of informational frictions.

In accordance with the general definition of the International Labour Organization (ILO), labour market information comprises of all kinds of knowledge related with the structure and extent of the labour market. The structure and extend of the market, together with supply and demand, also relate to the social structure. The industry 4.0 formed by phenomenological new concepts such as internet of things, big data, digital technologies, virtual currencies, artificial intelligence and innovation, rendered it difficult to understand and define the continuously developing and broadening borders of networks beyond markets. The strategic decision making and learning processes, which are embedded in expectations models of economic agents, are getting more 
complex by cumulatively growing global integrations. The information systems that are decisive in qualified and unqualified employees' search for work in the labour market also lead to changes in the formation of the division of labour. The classical proposition which asserts that the division of labour is limited with the extent of the market, now opens and paves new ways of philosophical interpretations and scientific intuitions by the introduction of information technologies.

Motivated by the characteristic conditions of an innovative paradigm shift, global socioeconomic transformation of societies and modus operandi of the business world, this article analytically, theoretically and practically examines the innovation based structural reforms and novelties in information systems infrastructure of ILO under a new construction of economic systems in a changing world. The plan of the article is as follows. The introductory first part depicts fundamental elements and background of the work in the context of adaptation and integration processes of global economies to large scale technological changes in the world. The second part is devoted to a comprehensive literary review and to the theoretical apprehension for organizational integration of information systems innovation in a conceptual framework.

The third part deals with the theory of functional and strategic information systems innovation. Different types of information systems innovations are defined according to particular organizational innovation models in the literature, and then information systems of innovation are set into a structural context of innovation ecosystems per se comprised of complex international systems of innovation. The fourth part is appropriated for innovation based structural reforms of ILO. These reforms fall under three chief functional categories, and each category signifies a particular portfolio in the hierarchical structure of the ILO headquarters. These three portfolios are the policy portfolio, management and reform portfolios, and field operations and partnership portfolios. Information systems of each portfolio are also examined in separate sections of the fifth part. The sixth part concludes with a general discussion and appreciation of the subject matter. Functional and strategic effects of structural reforms in the very constitution of the ILO indicate successful fulfilments of its chief aims. As a result, Keynesian coordination problems in global markets are also alleviated by the use of information technologies in the organizational infrastructure. 


\section{International Labour Organization and Information Systems Innovation}

Günümüzde piyasa tanımı ve kapsamı geleneksel neoklasik iktisat teorisinin sınırlarını aşarak sürekli bir gelişim ve genişleme göstermektedir. Klasik geleneksel mal ve işgücü piyasaları, iktisattaki standart arz ve talep mekanizmasının uzun dönem denge durumu varsayımları ile yapısal bir fonksiyon kazanmaktaydı. 21. yüzyılda hızla gelişen teknolojinin yanı sıra değişen iktisadî ve sosyal yapı yeni trendlerin oluşumuna neden olmaktadır. İşçi ve işverenlerin, girişimcilerin ve diğer iktisadî aktörlerin karar alma süreçlerinde yeni küresel trendlerle birlikte enformasyonun önemi de artmıştır. Yenilikçi girişimcilerin teknoloji ve inovasyon temelli üretim planları özellikle talep dinamikleri üzerinde etkileyici ve belirleyici olmaktadır.

İşgücü arz ve talebinin tam istihdam seviyesinde dengede olması için işgücü piyasasındaki enformasyonun miktarının ve maliyetinin optimum noktada bulunması gerekmektedir. Makro iktisadî dengelerin mikro altyapısının kurulmasına yönelik olarak piyasa enformasyon sistemlerinin teknoloji temelli inovasyonu ön plana çıkmaktadır. Piyasalardaki enformasyon akışı iktisadî kurumlar yoluyla ekonomide yayılma gösterirken uluslararası örgütler içindeki enformasyon sistemleri inovasyonu, Keynezyen koordinasyon hatalarını minimuma indirerek piyasaların dengelenme süreçlerini hızlandırmaktadır.

Uluslararası Çalışma Örgütü’nün tanımına göre işgücü piyasası enformasyonu, işgücü piyasasının yapısı ve kapsamı ile ilgili olan her türlü bilgiyi içermektedir. Piyasanın yapısı ve kapsamı ise arz ve talep dinamikleri ile birlikte sosyal yapı ile de ilgilidir. İnternet teknolojileri ve şirketleri, büyük veri, yapay zekâ ve inovasyon ile şekillenen Endüstri 4.0, ekonomileri dönüştürürken sosyal ağlar sayesinde sürekli genişleyen ve gelişen piyasa sınırlarını modern iktisatçılar tanımlamakta zorlanmaktadırlar.

İktisadî aktörlerin beklenti modelleri içinde yer alan stratejik karar alma ve öğrenme süreçleri küresel entegrasyonla birlikte giderek daha karmaşıklaşmaktadır. Endüstri 4.0 çağında vasıflı ve vasıfsız işçilerin işgücü piyasasındaki iş arayışlarında belirleyici olan işgücü piyasası enformasyon sistemleri geleneksel işbölümü anlayışı üzerinde de değişimlere neden olmaktadır. Stigler'in (1951) makalesine başlık olarak aldığı Adam Smith'in işbölümünün piyasa kapsamı ile sınırlı olduğu yönündeki klasik önermesi enformasyon teknolojileri ile 
birlikte yeni yorumlara yol açmakta ve piyasa yapısını oluşturan monopolcü ve rekabetçi dinamikleri düzenlemektedir.

Değişen dünyadaki iktisadî sistemin yeni yapılanması içerisinde Uluslararası Çalışma Örgütü'nün inovasyon temelli yapısal reformlarını ve enformasyon sistemleri altyapısındaki yenilikleri teorik, analitik ve pratik düzlemde araştıran bu makale altı bölümden oluşmaktadır. Giriş niteliğindeki birinci bölümde küresel ekonomilerin değişim süreçlerine adapte ve entegre olmaları bağlamında çalışmanın arka planı ve içeriğine ilişkin temel bilgiler anlatılmaktadır. İkinci bölümde enformasyon sistemleri inovasyonunun örgütsel entegrasyonu, belirli bir kavramsal çerçeve içine yerleştirilerek konunun teorik temelleri incelenmekte ve kapsamlı bir literatür araştırması yapılmaktadır.

Üçüncü bölümde fonksiyonel ve stratejik inovasyon sistemleri teorisi, enformasyon sistemleri inovasyonu türleri ve enformasyon sistemleri inovasyonunun bağlamsal yapısını oluşturan inovasyon ekosistemleri anlatılmaktadır. Dördüncü bölüm, Uluslararası Çalışma Örgütü’ndeki inovasyon temelli yapısal reformlara ayrılmıştır. Beşinci bölümde, Uluslararası Çalışma Örgütü bünyesindeki enformasyon sistemleri ayrıntılı bir şekilde incelenmektedir. Makale, genel bir değerlendirme ile altıncı bölümde sonuçlanmaktadır.

\section{Enformasyon Sistemleri İnovasyonunun Örgütsel Entegrasyonu: Kavramsal Çerçeve, Teori ve Literatür}

Literatürde örgütsel inovasyon ile ilgili araştırmalar genellikle inovasyonun enformasyon teknolojileri yoluyla piyasalardaki ve örgütler içindeki yayılma etkileri üzerine yoğunlaşmıştır. Bilginin sosyal yapı içerisinde ekonomiye fayda sağlayacak bir fonksiyonellik kazanması sayesinde piyasa değeri olan enformasyona dönüşmesi Endüstri 4.0 ile birlikte hız kazanmıştır.

Günümüzde inovasyonun örgütler ve firmalar arasındaki yayılma hızı, enformasyonun piyasalardaki dolaşım hızı ile yakın bir korelasyon içindedir. Enformasyon teknolojilerinin örgüt yapıları ve tasarımları üzerindeki etkileri stratejik süreçlerle giderek daha karmaşık bir hal almaktadır. Enformasyon teknolojilerinin örgütsel inovasyon süreçlerine entegre olma modellerinde yeni teknolojiler, örgütsel inovasyonun kümülatif fonksiyonuna marjinal bir katk1 olarak değerlendirilmektedir (Buitendam \& Pennings, 1987, s. 251). 


\section{Uluslararası Çalışma Örgütü İnovasyon Sistemi}

İnovasyonun yayılma etkisi, yeni teknolojilerin artan marjinal faydaları ile doğru orantılı olarak çoğalmaktadır. Örgütler tarafından zaman içinde benimsenen inovasyonlar enformasyon teknolojilerinin trendlerini takip etmektedirler. Normal dağılıma göre gerçekleşen benimsenme süresinde inovasyonun kümülatif modeli 'S' eğrisi şeklinde olacaktır (Rogers, 1983, s. 37). Hizmet ve süreç inovasyonlarının hayat döngüleri birbirlerinden farklı trendlere sahip olmakla birlikte inovasyonların benimsenme süreleri, gözlem sayısı arttıkça normal dağılım özellikleri göstermektedir.

Vagnani vd. (2019, s. 4) örgütler içindeki inovasyonların yayılma ve benimsenme süreçlerine ilişkin olarak geliştirdikleri meta-analitik bir literatür araştırmasıyla kavramsal bir çerçeve çizmektedirler. Bu araştırma kapsamında inovasyon kavramı gelişmiş bir sosyal yapı olan örgüt içerisinde sosyal sermaye birikimine ivme kazandıran verimli bir üretim kaynağı şeklinde kullanılmak üzere geliştirilen bir enformasyon sistemi olarak tanımlanmaktadır (Zaltman vd., 1973, s. 76). Kavramsal çerçevede daha genel bir tanım yapan Rogers (1983, s. 35), inovasyonu iktisadî aktörler ve kurumlar tarafından yenilik olarak kavranan bir üretim fikri, projesi veya faaliyeti ile ifade etmektedir.

\section{Kavramsal Çerçeve}

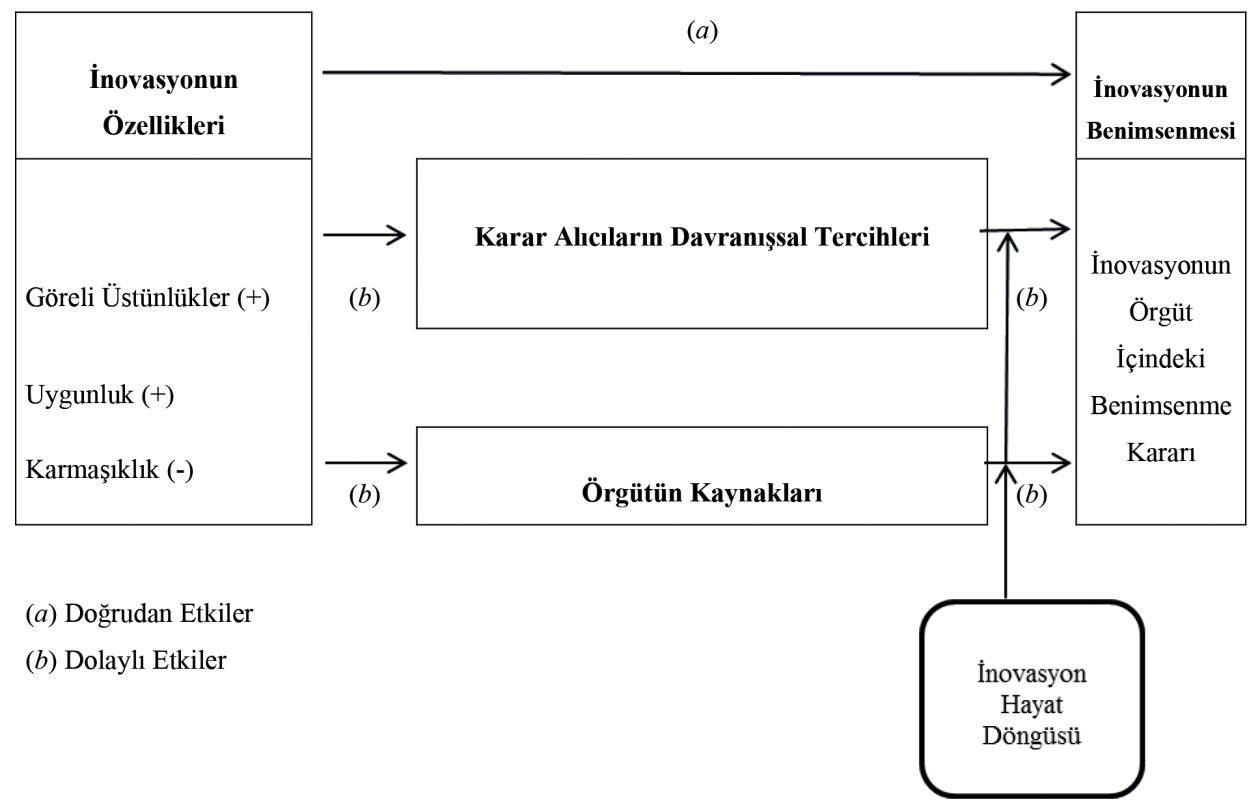

Şekil 1. Örgütsel İnovasyon sistemi

Kaynak: Vagnani vd. (2019, s. 4) 
Şekil 1.'deki Örgütsel İnovasyon Sistemi ile enformasyon sistemlerinin örgütsel entegrasyonunu çok boyutlu bir kavramsal çerçeve içerisine yerleştiren Vagnani vd. (2019, s. 4) karar alma süreçlerinde çeşitli kaynakların etkili olduğunu belirtmektedir. Uluslararası Çalışma Örgütü'nün inovasyon sistemi modeli olan Örgütsel İnovasyon Şeması iki kısma ayrılmaktadır. İlk kısımda inovasyonun özelliklerinin, inovatif faaliyetlerin örgüt içindeki benimsenme kararı üzerinde doğrudan ve dolaylı etkileri belirtilmektedir. Doğrudan etkiler inovasyonun örgüt içinde objektif olarak benimsenmesini sağlarken dolaylı etkiler sübjektif bir benimsenme sürecine neden olur. $(a)$ ile ifade edilen doğrudan etkiler inovatif faaliyetlerin örgüt tarafından herhangi bir kısıtlamaya veya yoruma tâbi olmaksızın objektif olarak benimsendiği durumu göstermektedir. Bu durumda inovasyonun örgütsel entegrasyonu herhangi bir idarî prensipten veya kontrol mekanizmasından etkilenmeksizin doğrudan gerçekleşmektedir.

Örgütsel İnovasyon Sistemi'nin ikinci kısmında, Şekil 1.'de (b) ile ifade edilen dolaylı etkiler ise inovatif faaliyetlerin karar alıcıların davranışsal tercihlerinden ve/veya örgütün kaynaklarından etkilendiği sübjektif durumu göstermektedir. Bu durumda ise inovasyonun özellikleri göreli üstünlükler, uygunluk ve karmaşıklık bileşenlerine göre değerlendirilmektedir. Göreli üstünlükler ve uygunluk, Uluslararası Çalışma Örgütü'ndeki yöneticilerin ve karar alıcıların davranışsal tercihleri üzerinde pozitif bir etki yaparken karmaşıklık negatif etki yapmaktadır. Örgütün kaynakları, inovasyonun örgütsel entegrasyonu üzerinde bir bütçe kısıtı oluşturmaktadır. Ar-Ge harcamaları ve inovasyon yatırımı kararlarında bütçe kısıtı önemli etkilere sahiptir.

\section{Uluslararası Çalışma Örgütü İnovasyon Fonksiyonu}

İnovasyonun örgütler, kurumlar ve iktisadî aktörler arasındaki adaptasyon ve entegrasyon süreçleri ve kararları analiz düzeyine göre değişmektedir. İnovasyonun yayılma teorisi ile planlı davranış teorisinin, bireylerin ve örgütlerin inovasyonu benimseme kararları üzerindeki etkileri farklılıklar göstermektedir (Weigel vd., 2014, s. 35). Bu farklı etkiler parametrik bir fonksiyon ile ifade edilebilir. İnovasyonu bir süreçten çok, bir fonksiyon olarak tanımlamak inovasyon sisteminin örgütsel yapı içerisindeki entegrasyonunu kolaylaştıracaktır. Optimal araştırma ve öğrenme süreçleri ile enformasyonun piyasadaki dolaşım ve yayılma hızı üzerine çalışmalar literatürde artarken, inovasyonun formüle 
edilmesi süreç ve sistem yaklaşımlarının bütünlük kazanması için gereklidir (Sorensen \& Fleming, 2004, s. 1617).

İnovasyon süreçlerinde örgütsel karar mekanizması Uluslararası Çalışma Örgütü yönetim kurulu tarafından idare edilmektedir. Örgüt yönetim kuruluna ait karar kriterleri ise a priori olarak belirlenmiştir (O'Connor, 2012, s. 362). Örgütsel inovasyon fonksiyonu, örgütün stratejik inovasyon kararlarının dinamik bir şekilde açıklanmasında kullanılabilir. İnovasyon fonksiyonu, Ar-Ge faaliyetlerinin geliştirilmesi konusunda da fikir sağlayabilir. Lawrence ve Lorsch'un (1967) örgüt tasarımı, yapısı ve hiyerarşisi ile inovasyon arasındaki entegrasyonun altyapısını oluşturan klasik örgüt teorisi, örgütsel inovasyon fonksiyonu ile daha bütünsel bir sistem içerisine yerleştirilebilir.

İnovatif faaliyetlerin doğrudan ve dolaylı etkilerini formüle etmek için Şekil 1.'deki akış şemasıyla gösterilen ve inovasyon süreçlerini tarif eden Örgütsel İnovasyon Sistemi'ni, Örgütsel İnovasyon Fonksiyonu'na dönüştürmemiz gerekmektedir. İki kısımdan oluşan Örgütsel İnovasyon Sistemi'ni parçalı fonksiyon ile gösterebiliriz. İnovatif faaliyetlerin $(a)$ ve $(b)$ ile ifade edilen doğrudan ve dolaylı etkilerini de $(\alpha)$ ve $(\beta)$ parametreleri ile tanımlayabiliriz. Buna göre, Örgütsel İnovasyon Fonksiyonu'nun formülasyonu aşağıdaki gibi olacaktır.

$f: R \rightarrow R, f(x)=\left\{\begin{array}{cc}g(x)=\alpha x_{t+1}+\gamma, & 0<\alpha \leq 1 . \\ h(x)=\beta x_{t-1}+\phi, & -1 \leq \beta<0 . \\ r(x)=(\alpha+\beta) x_{t}+\lambda, & -1 \leq(\alpha+\beta) \leq 1 .\end{array}\right.$

(1) numaralı denklem örgütsel inovasyonun parçalı parametrik fonksiyonunu ifade etmektedir. $(\alpha)$ ve $(\beta)$ parametreleri doğrudan ve dolaylı etki faktörlerini göstermektedir. Fonksiyonun tanım kümesinde göreli üstünlükler, uygunluk ve karmaşıklık olmak üzere inovasyonun özellikleri $(x)$ bağımsız değişkeni ile tanımlanırken, değer kümesinde inovasyonun örgüt içindeki benimsenme kararı yer almaktadır. Parametrik etki faktörlerinin pozitif ve negatif ağırlıkları inovasyonun benimsenme kararı üzerinde belirleyici olmaktadır.

(1) numaralı denklemde reel sayılardan reel sayıların bir alt kümesine tanımlanan $f(\mathrm{x})$ fonksiyonunun ilk parçası, $(\alpha)$ parametresi ile ifade edilen 
doğrudan etki faktörünün 0 ilâ 1 arasında pozitif değerler aldığı $g(x)$ fonksiyonudur. Herhangi bir $\{t\}$ döneminde bir sonraki $\{t+1\}$ dönemindeki inovasyonun doğrudan benimsenmesi Uluslararası Çalışma Örgütü’nün merkezî yönetimindeki karar mekanizmasının rasyonel beklentiler modeline göre gerçekleştiğini göstermektedir.

Fonksiyonun ikinci parçası $(\beta)$ parametresi ile ifade edilen dolaylı etki faktörünün 0 ilâ -1 arasında negatif değerler aldığı $h(\mathrm{x})$ fonksiyonudur. $\mathrm{Bu}$ durumda, Şekil 1.'deki Örgütsel İnovasyon Sistemi'nde inovasyonun özellikleri arasında yer alan karmaşıklık, inovasyonun örgüt içindeki benimsenme kararı üzerinde ağırlıklı olarak negatif bir etki yapmaktadır. Herhangi bir $\{t\}$ döneminde bir önceki $\{t-1\}$ dönemindeki inovasyonun dolaylı olarak benimsenmesi örgütsel karar mekanizmasının adaptif beklentiler modeline göre işlediğini göstermektedir.

Örgütsel İnovasyon Fonksiyonu'nun üçüncü parçası ise $(\alpha)$ ve $(\beta)$ parametrelerinin toplamından oluşan doğrudan ve dolaylı etki faktörlerinin -1 ilâ +1 arasında hem negatif hem pozitif değerler aldığ 1 karma $r(\mathrm{x})$ fonksiyonudur. Herhangi bir $\{t\}$ döneminde cari dönemdeki inovasyonun dolaylı ve dolaysız etkilerinin bir arada değerlendirilerek benimsenmesi, örgütsel karar mekanizmasının öğrenme süreçlerine dayalı Bayesyen beklentiler modeline göre işlediğine işaret etmektedir. Bu karma fonksiyon, inovasyonun Uluslararası Çalışma Örgütü içindeki benimsenme kararının stratejik doğasına uygun bir parametrik yapıya sahiptir.

İnovasyon süreçlerindeki belirsizlik, Örgütsel İnovasyon Fonksiyonu'nda da yer almaktadır. Örgütsel inovasyon süreçlerindeki belirsizlik araştırmaları örgüt içindeki inovasyon kararlarının belirsizlik koşullarında alındığını ortaya koymaktadır (Allen, 1982, s. 602; Damanpour, 1991, s. 560). Karma fonksiyonun pozitif ve negatif parametrelerinin toplamından oluşan $(\alpha+\beta)$ net etki faktörünün sıfır olması durumunda inovatif faaliyetlerin belirsizlik yönetimine göre stratejik karar mekanizması Uluslararası Çalışma Örgütü’nün merkezî yönetimindeki karar alıcıların davranışsal tercihleri doğrultusunda gerçekleşecektir.

Beklenti modellerindeki hata terimleri ve piyasa koordinasyon problemleri inovasyon sürecine de belirsizlik olarak yansımaktadır. Örgüt ekonomisi araştırmalarında belirsizlik önemli bir yer tutmaktadır. Jalonen (2012) inovasyon sürecinde belirsizlik yaratan sekiz faktörden söz eder. Bu belirsizlik faktörleri 
sırasıyla teknolojik belirsizlik, piyasa belirsizliği, kurumsal belirsizlik, uygunluk belirsizliği, idarî belirsizlik, zamanlama belirsizliği ve sonuç belirsizliği olarak adlandırılmaktadır (Jalonen, 2012, s. 14).

\section{Fonksiyonel ve Stratejik Enformasyon Sistemleri İnovasyonu Teorisi}

Enformasyon sistemleri inovasyonu, enformasyon teknolojileri olarak adlandırılan dijital bilgisayarlar ve iletişim teknolojilerinin Uluslararası Çalışma Örgütü içerisindeki uygulamalarını tanımlamak için kullanılan genel bir kavramdır. Örgüt yapısındaki fonksiyonel farklılaşma, örgütsel inovasyon teorisinin temelini oluşturmaktadır. Daft'ın (1978) çift fazlı örgütsel inovasyon modeli, idarî inovasyon ve teknik inovasyon olmak üzere ikiye ayrılmaktadır.

Yeni bir fikrin veya davranışın örgüt tarafından benimsenmesi olarak tanımlanan örgütsel inovasyon sürecinde 'yenilik' kavramı da görelilik kazanmaktadır. "Neye göre yeni?” sorusuna verdikleri cevapta Becker \& Whisler (1967, s. 463) inovasyonu örgütün teknolojik çevresine göre yeni olan fikir veya davranışlar olarak tanımlamaktadırlar. Günümüzdeki küresel inovasyon ekosistemleri ve enformasyon ağları, yenilik kavramının göreli anlamlarını ortadan kaldırmakta ve inovasyonu evrensel bir platforma taşımaktadır.

Daft'1n (1978) örgütsel inovasyon modelinde idarî ve teknik birimler inovasyon sürecinde farklı roller üstlenmektedirler. Bu roller özelliklerine göre şöyle sıralanabilir: (i.) İdarî ve teknik birimlerdeki grupların her birinden kendi örgütsel görevleriyle ilgili olarak inovasyon inisiyatifi almaları beklenmektedir. (ii.) Bu işbölümü, profesyonelliği artırmak ve örgüt yapısını optimize etmek için gereklidir. (iii.) Profesyonellik arttıkça ve optimum örgüt büyüklüğüne ulaşıldıkça her bir grup tarafından önerilen inovasyon inisiyatiflerinin mutlak sayısında da artış beklenmektedir. (iv.) İnovasyon önerilerinin artan sayıları, inovasyonun örgüt içindeki benimsenme oranını artırmayabilir çünkü profesyonellik ve optimum büyüklük aynı zamanda inovasyonun benimsenmesinde direnç faktörü olarak yöneticilerin karşısına çıkmaktadır (Daft, 1978, s. 197).

Swanson (1994) örgütler arasındaki enformasyon sistemleri inovasyonu teorisinin temellerini kuracak bir model geliştirmiştir. Enformasyon sistemleri inovasyonunun temel türlerini ortaya koyan bu model Daft'ın (1978) çift fazlı örgütsel inovasyon modelinin bir aç1lımıdır. Swanson'un (1994) idarî ve teknik fazlı örgütsel inovasyon modeline fonksiyonel enformasyon sistemlerini ilk 
iki temel birimi birbirine bağlayan üçüncü bir faz olarak ekleyen üç fazlı modeli, enformasyon sistemleri inovasyonunun Uluslararası Çalışma Örgütü yapısı içinde daha görünür kılınmasını sağlamaktadır. Örgütlerin bürokratik yapıları inovasyon süreçlerinde fonksiyonel enformasyon sistemlerinin, idarî ve teknik birimler tarafindan kamufle edilmesine neden olmaktadır (Daft, 1982, s. 140).

\section{Uluslararası Çalışma Örgütü Enformasyon Sistemleri İnovasyonu Türleri}

Örgütsel inovasyon modelinin üç fazlı versiyonu, enformasyon sistemleri inovasyonunun modelin her üç bileşenini de kapsadığı özel bir durumdur. Buna göre fonksiyonel enformasyon sistemi modele yeni bir faz olarak eklenirken idarî ve teknik fazlar enformasyon sistemleri ürün ve hizmetleri ile bağlantılı hâle gelmektedir.

Üç fazlı modeli dikey bir silindirin yatay dairesel kesiti olarak düşündüğümüzde en içteki ilk kesitte teknolojik faz, ortadaki ikinci kesitte enformasyon sistemleri fazı ve en dıştaki üçüncü kesitte ise idarî faz yer almaktadır. Dairesel kesitin içerisinden dışarısına doğru genişleyen fazlar arasındaki bağlantı ise enformasyon teknolojileri sayesinde sağlanmaktadır. Dikey silindirin alt kısmından başlayan üretim aşaması katma değer sürecinden geçerek üst kısmında sona ermektedir. Bu yapı aynı zamanda Porter'ın (1988) enformasyon hiyerarşileri modeline de uygun bir özellik göstermektedir.

Swanson (1994) üç fazlı örgütsel inovasyon modelinde, enformasyon sistemleri inovasyon türlerini temel bir analiz düzeyine göre üç ana tipoloji ve onların alt türleri olarak belirlemektedir.

1. Birinci tür enformasyon sistemleri inovasyonu: İdarî süreç inovasyonu olarak adlandırılan bu tür bir inovasyon süreci sırf fonksiyonel enformasyon sistemleri fazı ile sınırlandırılmıştır. Uluslararası Çalışma Örgütü enformasyon sistemlerindeki inovatif faaliyetlerin örgüt yönetimi tarafından teknik olarak desteklendiği durumları ifade eder. Bu inovasyon türü kendi içinde ikiye ayrılmaktadır. İdarî enformasyon sistemleri birinci tür $(a)$ kategorisinde yer alırken, teknik enformasyon sistemleri birinci tür $(b)$ kategorisinde yer almaktadır.

2. İkinci tür enformasyon sistemleri inovasyonu: Hizmet ve iş idaresi süreci inovasyonu olarak adlandırılan bu tür bir inovasyon süreci örgütsel inovasyon 
modelinin idarî fazında kullanılan enformasyon sistemleri ürün ve hizmetlerini içermektedir. Uluslararası Çalışma Örgütü bünyesindeki bilgi merkezi hizmetleri ve sistem analizleri ikinci tür inovasyona örnek olarak verilebilir. $\mathrm{Bu}$ inovasyon türü, birinci tür inovasyonun bazı özelliklerini de kapsamaktadır.

3. Üçüncü tür enformasyon sistemleri inovasyonu: Bu türdeki inovasyonlar üç alt kategoriye ayrılmaktadır. Birinci tür $(a)$ kategorisinde hizmet ve teknolojik süreç inovasyonu yer alırken ikinci tür $(b)$ kategorisinde ürün ve hizmet inovasyonu bulunmaktadır. Üçüncü ve son $(c)$ kategorisinde ise ürün ve hizmet entegrasyonu inovasyonu sistemi tamamlamaktadır. Bu kategorideki inovasyon sistemleri Uluslararası Çalışma Örgütü’nün departmanları ve 4. Bölüm'de incelenen yapısal reformlarla kurulan birimler arasında koordinasyon sağlamak için idarî ve enformasyon sistemleri altyapısıyla da eşgüdüm içerisinde çalışmaktadır.

“Uluslararası Çalışma Örgütü’ndeki Yapısal Reformlar ve İnovasyon,” başl1kl1 4. Bölüm'de görüleceği üzere, yeni örgütsel yapılanmalarda Chandler'ın (1977) idarî reform kavramıyla Adam Smith'e atfen 'görünür el' olarak ifade ettiği klasik yatay ve dikey entegrasyonunun yanı sıra enformasyon teknolojilerinin ve Child (1987) tarafindan incelenen farklı modlardaki stratejik örgütsel yapılanmaların geçerli olduğu Endüstri 4.0 çağında Uluslararası Çalışma Örgütü bünyesinde ve altyapısında enformasyon sistemleri entegrasyonuna uygun reformlar gerçekleşmektedir.

\section{Uluslararası Çalışma Örgütü Enformasyon Sistemleri İnovasyonunun Bağlamsal Yapısı: İnovasyon Ekosistmeleri}

Enformasyon sistemleri inovasyonunun örgütsel entegrasyonunda etkili olan içsel faktörler kadar dişsal faktörlerin de değerlendirilmesi gerekmektedir. Günümüz küresel ekonomilerinde inovasyon ekosistemleri olarak da adlandırılan çevresel ve küresel faktörler Uluslararası Çalışma Örgütü’nün bağlamsal yapısı içerisinde fonksiyonellik kazanmaktadırlar (Tornatsky \& Fleischer, 1990, s. 27).

Amerika Birleşik Devletleri Rekabet Kurulu tarafından '21. Yüzyılda İnovasyon’ başlığı altında yapılan çalışmalar sonucunda Ulusal İnovasyon Ekosistemi planı geliştirilmiştir. Bu plana göre, 21. yüzyılda ekosistem kavramından hareketle teknoloji politikalarından inovasyon politikalarına doğru bir geçiş yaşanmaktadır (Council on Competitiveness, 2004, s. 10). 
Büyüme, İstihdam, Hayat Standardı, Refah, Karşılaştırmalı Üstünlükler

İnovasyonun Dolaşım Hızı, Kalitesi, Verimliliği ve Kârılığı
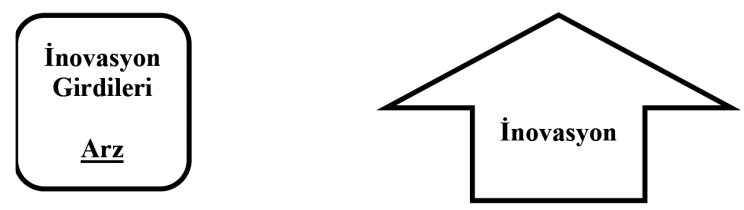

Inovasyon

Çıktıları

$\underline{\text { Talep }}$

Politika Cevresi

Ulusal Altyapı

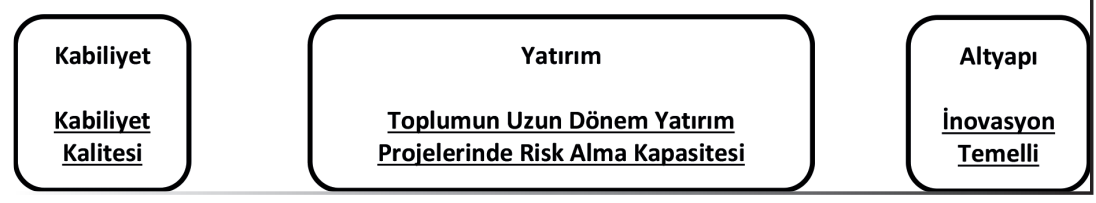

Şekil 2. Ulusal inovasyon ekosistemi

Kaynak: Council on Competitiveness (2004)

Rekabet Kurulu tarafından tarif edilen Şekil 2.'deki Ulusal İnovasyon Sistemi beş ayrı önerme temeline dayanmaktadır. Bu önermeler post-endüstriyel ve post-enformasyon toplumlarında lineer olmayan dinamiklerle karakterize edilen küresel inovasyon ekosistemlerinin temel bileşenlerini içermektedir (Watanabe ve Fukuda, 2005, s. 3).

ÖNERME 1. İnovasyon sırf bir teknolojiden daha fazlasını ifade eder. Piyasaların Keynezyen koordinasyon hatalarının telâfi edilerek denge durumuna uyarlanma süreçlerinin sürat kazanması için her defasında fazladan kaynak, mal ve hizmet tedarikinin yanı sıra stratejik ve lojistik destek sağlanması da gerekmektedir. Toplumun uzun dönem yatırım projelerinde risk alma kapasitesi beşerî sermayenin marjinal verimliliği ile yakından ilgilidir. Beşerî sermayenin marjinal verimliliği sosyal ve bireysel girişimcilik fonksiyonları ile ifade edilebilir.

ÖNERME 2. İnovasyon dinamiklerini fonksiyonel olarak tarif ve tahmin etmek için disiplinlerarası bir yaklaşıma ihtiyaç vardır. 
İnovasyon süreçlerinin ve sistemlerinin çok boyutlu ve karmaşık yapısı tek taraflı yaklaşımlarla anlaşılamaz. Kalitatif ve kantitatif metodolojilerin birlikte kullanıldığı çok değişkenli ve lineer olmayan modeller özellikle paradigma inovasyonlarını açıklamakta daha başarılı olurlar. Paradigma inovasyonları ekonominin uzun dönem denge durumundan, tam olarak beklenmeyen teknolojik bir dış şokla kalıcı bir şekilde uzaklaştı̆̆ 1 ve alt bir denge durumundan üst bir denge durumuna geçiş süreci içinde yaşadığı köklü dönüşümleri ve değişimleri ifade eder.

ÖNERME 3. İnovasyonun piyasa başarısı, kurumlar ve örgütler içerisindeki dolaşım hızı ve endüstrilerarası yatay ve dikey entegrasyon etkisi nihayetinde ekonominin talep cephesi tarafindan belirlenmektedir. Arz cephesi bileşenleri arasında sayılabilecek girişimcilik, teknoloji ve üretim faktörleri piyasada efektif talep yaratabilme kabiliyetleri ölçüsünde rekabet güçlerini artırabilirler. Toplumdaki inovasyon temelli altyapı yatırımları da uzun dönemde inovasyonun başarısı üzerinde etkili olmaktadır.

ÖNERME 4. Örgüt ekonomileri piyasa arz ve talep dinamiklerinin dikotomik yaklaşımının dışında uluslararası inovasyon kaynaklarına ve küresel piyasaların inovasyon dinamiklerine erişimleri ölçüsünde iktisadî aktörlerle karşılıklı etkileşim ve işbirliği içerisinde gelişme gösterebilirler. Ulusal İnovasyon Ekosistemi’nin inovasyon girdileri ve çıktıları arz ve talep dinamikleri tarafından dengelenmektedir.

ÖNERME 5. Yüksek katma değerli mal ve hizmet üretiminde öğrenme süreçlerine dayalı lineer olmayan dinamik faktörler inovasyon sistemleri üzerinde belirleyici etkilere sahiptirler. İnovasyon analizi yapılırken öğrenme süreçlerine dayalı dinamik modellerin kullanılması gerekmektedir. Beklenti oluşumu ve beklentilerin modellenmesi de inovasyon yatırımı planları için önem taşımaktadır. Rasyonel beklentiler hipotezi ekonominin uzun dönem durağan denge durumuna odaklanırken öğrenme süreçlerine dayalı Bayesyen beklentiler hipotezi ekonominin alt bir denge durumundan üst bir denge durumuna kademeli 
geçiş sürecindeki dengesizlik dönemine odaklanmaktadır. Ekonominin denge durumuna uyarlanma süreci ve inovasyonların yayılma hızı arasında pozitif bir korelâsyon vardır.

Ulusal İnovasyon Ekosistemi'nin büyüme, istihdam, hayat standardı, refah ve karşılaştırmalı üstünlükler olmak üzere ülke ekonomilerinin kalkınmaları için önemli makro iktisadî büyüklükler üzerinde etkileri vardır. İnovasyon temelli altyapı yatırımları ve yenilikçi girişimcilik faaliyetleri bir ülkedeki makro iktisadî sistemin mikro altyapısının oluşmasına zemin hazırlar. Krugman'ın (1979) genel denge modeli ile kuramsallaştırdığı ülkeler arasındaki teknoloji transferi ve inovasyon, uluslararası ticaretin karşılaştırmalı üstünlükler teorisinin modern bir yorumu olarak literatürde yeni araştırmalara konu olmaktadır.

Şekil 1.'deki Örgütsel İnovasyon Sistemi’nin kapalı devre akış şeması içerisinde doğrudan ve dolaylı etki faktörleri küresel inovasyon ekosistemi bağlamında düşünüldüğünde, stratejik bir planda dışa açık bir model ile analiz düzeyinin daha geniş tutulması gerekmektedir. Uluslararası Çalışma Örgütü'nde inovasyonların benimsenme ve yayılma etkileri dışa açık bir modelde bir akış şeması ile aşağıdaki gibi gösterilebilir.

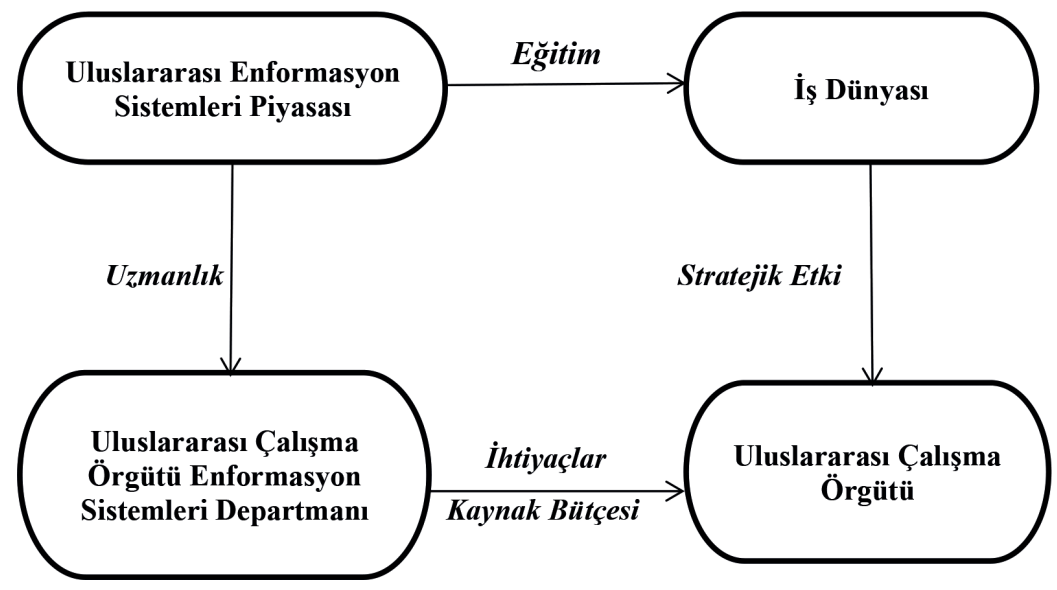

Şekil 3. Uluslararası Çalışma Örgütü Enformasyon Sistemleri

Kaynak: Swanson (1994, s. 1079)

Şekil 3.'deki akış şeması, Uluslararası Çalışma Örgütü’nün idarî, teknik ve enformasyon sistemleri inovasyonundan oluşan üç fazlı bir örgütsel yapılanma modelini göstermektedir. Bu model, Uluslararası Çalışma Örgütü’nün inovasyon temelli yapısal reformlarını yansıtmaktadır. 


\section{Uluslararası Çalışma Örgütü’ndeki Yapısal Reformlar ve İnovasyon}

Uluslararası Çalışma Örgütü'nün genel yapılanması içinde 1970'li ve 80'li yıllardaki idarî ve teknik departmanlaşma, Daft'ın (1978) çift fazlı örgütsel inovasyon modeline uygundur. 21. yüzyılda hız kazanan küreselleşme ile Uluslararası Çalışma Örgütü’nün merkezî yapılanmasında reformlar gerçekleşmiştir. Uluslararası Çalışma Örgütü’ndeki yapısal reformlar, 10 Haziran 2008 tarihinde Cenova'da gerçekleştirilen Uluslararası İşgücü Konferansı'nda imzalanan Adil Küreselleşme İçin Sosyal Adalet Deklarasyonu ile yürürlüğge girmiştir. Bu yapısal reformlar, Uluslararası Çalışma Örgütü’nün iş dünyasında küresel anlamda itibarlı bir otorite olma hedefini ve kuruluş prensiplerini yansitmaktadır (ILO, 2008).

Uluslararası Çalışma Örgütü'nün merkezî genel örgüt yapısında gerçekleşen reformlar enformasyon sistemleri inovasyonunu kapsayan bir dizi düzenlemeyi içermektedir. Reformların ardından Uluslararası Çalışma Örgütü’nün idarî ve teknik enformasyon sistemleri üç birime ayrılmıştır. Bunlar (i.) Politika Birimi, (ii.) Yönetim ve Reform Birimi, (iii.) Saha Operasyonları ve Ortaklıklar Birimi olarak adlandırılmaktadır ve her birimin çeşitli departmanlardan oluşan farklı alt birimleri vardir (ILO, 2013, s. 2). Bu birimlerin her birini genel hedefleri ve hiyerarşik yapılanmaları açısından inceleyebiliriz.

\section{Politika Birimi}

Politika Birimi, Uluslararası Çalışma Örgütü'nün iş dünyasındaki itibarını ve otoritesini küresel gelişmeler karşısında güçlendirecek yeni politika önerileri ve analizleri yapmak üzere kurulmuştur. Soğuk Savaş döneminin sona ermesinin ardından örgütün kurumsal bütünlügünü olumsuz yönde etkileyen küreselleşme karşısında, kaide teşkil eden politikalar üretme ihtiyacı gündeme gelmiştir. 21. yüzyılda küreselleşme ve çok uluslu güçler, Uluslararası Çalışma Örgütü'nün normatif varlık nedenine yönelik risk unsurları olarak değerlendirilmektedir (Maupain, 2009, s. 825).

Genel Direktör Yardımcısı tarafından yönetilen Politika Birimi’nin ana hedefleri dört madde altında toplanabilir (ILO, 2013, s. 2-3).

- Küreselleşme ve enformasyon teknolojileriyle hızlı bir değişim ve dönüşüm yaşayan günümüz iş dünyasının giderek karmaşıklaşan iktisadî sistemine ve sosyoekonomik yapısına karşı entegre politika çözümleri üretmek. 
- Uluslararası Çalışma Örgütü’nün faaliyetlerinin küreselleşme ile birlikte yaşadığı bölünmüşlüğün üstesinden gelebilmek için eleştirel bir toplumsal çoğunluk inşa ederek örgüt yapısındaki reformlarla fonksiyonel farklılaşmaya gitmek yoluyla örgütsel inovasyon temelinde küresel entegrasyon sağlamak.

- Karmaşık küresel süreçler ve sorunlar karşısında işbirliği yoluyla çok disiplinli yaklaşımlar geliştirmek. Bu amacın gerçekleştirilmesinde Şekil 3'deki Uluslararası Çalışma Örgütü enformasyon sistemleri bileşenleri arasında yer alan uzmanlık ve stratejik etki faktörleri, örgütün iş dünyası ve uluslararası enformasyon sistemleri piyasası ile olan etkileşimleri önemli rol oynamaktadır.

- Üç fazlı örgütsel inovasyon modeline göre örgütsel hiyerarşide üst kademelerdeki araştırma ve politika geliştirme faaliyetlerini alt kademelerdeki uygulama alanlarıyla koordine ederek idarî ve teknik inovasyonu enformasyon sistemleri inovasyonuyla bağdaştırmak.

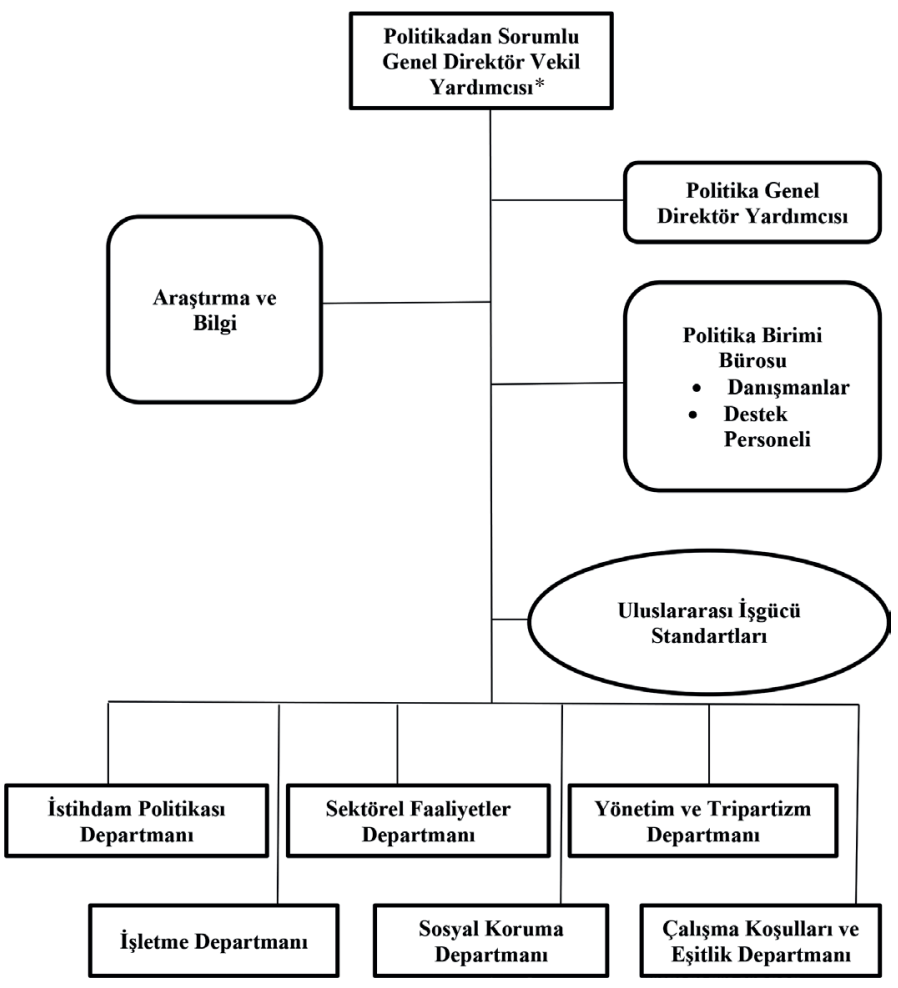

Şekil 4. Politika Birimi Hiyerarşik Yapılanması

Kaynak: ILO, Reform of the International Labour Organization's Headquarters Organizational Structure (2013). *Deputy Director-General for Policy 
Yatay bir örgütsel yapıya sahip olan Politika Birimi her biri Uluslararas1 Çalışma Örgütü'nün faaliyet sahasının önemli bir kısmını kapsayan altı ana teknik departmandan ve ek olarak bir de Uluslararası İşgücü Standartları Departmanı'ndan oluşmaktadır. Teknik departmanlar sırasıyla; (i.) İstihdam Politikası Departmanı, (ii.) İşletme Departmanı, (iii.) Sektörel Faaliyetler Departmanı, (iv.) Yönetim ve Tripartizm Departmanı, (v.) Çalışma Koşulları ve Eşitlik Departmanı ile (vi.) Sosyal Koruma Departmanı olarak adlandirılmaktadır (ILO, 2013, s. 4).

\section{Yönetim ve Reform Birimi}

Her türden destek hizmetlerinin sağlanmasından ve geliştirilmesinden sorumlu olan Yönetim ve Reform Birimi idarî faaliyetlerde verimliliğin artırılmasına ve maliyetlerin azaltılmasına yönelik çalışmalar yapmak üzere kurulmuştur. $\mathrm{Bu}$ birim, (3.1) numaralı kisımda bahsedilen ve temel olarak enformasyon sistemlerindeki inovatif faaliyetlerin Uluslararası Çalışma Örgütü merkezî yönetimi tarafından teknik olarak desteklendiği durumları ifade eden birinci tür enformasyon sistemleri inovasyonunu kapsamaktadır.

Genel Direktör Yardımcısı tarafindan yönetilen Yönetim ve Reform Birimi ana hedefleri beş madde altında toplanmaktadır (ILO, 2013, s. 5).

- İdarî yapıları bürokratik karmaşıklıklardan arındırıp birinci tür enformasyon sistemleri inovasyonunun (a) kategorisinde yer alan idarî enformasyon sistemleri sayesinde sadeleştirerek idarî verimliliği artırmak.

- Şekil 1'de gösterilen Örgütsel İnovasyon Sistemi'ndeki akış şemasına göre Uluslararası Çalışma Örgütü’nün merkezî yapılanmasındaki karar alma ve sorumluluk süreçlerini uyumlu hâle getirerek ve kolaylaştırarak inovasyon özellikleri arasında negatif etki faktörünü ifade eden karmaşıklık özelliğini ortadan kaldırmak.

- Uluslararası Çalışma Örgütü içerisindeki bütün birimleri ve departmanları koordine ederek inovasyon sistemindeki enformasyon akışını uluslararası enformasyon sistemleri piyasası ile senkronize etmek için esnek yönetimsel ve idarî destek sağlamak.

- Uluslararası Çalışma Örgütü İnovasyon Sistemi’ne entegre olan farklı yönetim fonksiyonları arasında uyum ve tutarlılık sağlamak. Bu hedef (1) 
numaralı parçalı örgütsel inovasyon fonksiyonunun $(\alpha)$ ve $(\beta)$ parametrelerinin toplamından oluşan doğrudan ve dolaylı etki faktörlerinin -1 ilâ +1 arasında hem negatif hem pozitif değerler aldığı karma $r(\mathrm{x})$ stratejik karar alma denklemi ile ilgilidir.

- Uluslararası Çalışma Örgütü'nün merkezî yönetim fonksiyonlarındaki ve idare kademesindeki birtakım verimsizlikleri gidermek. Bu hedef, Uluslararası Çalışma Örgütü'nün (2.2.1) numaralı parçalı inovasyon fonksiyonunun stratejik karar alma denklemi ile ifade edilen dinamik öğrenme süreçleri ile ilgilidir.

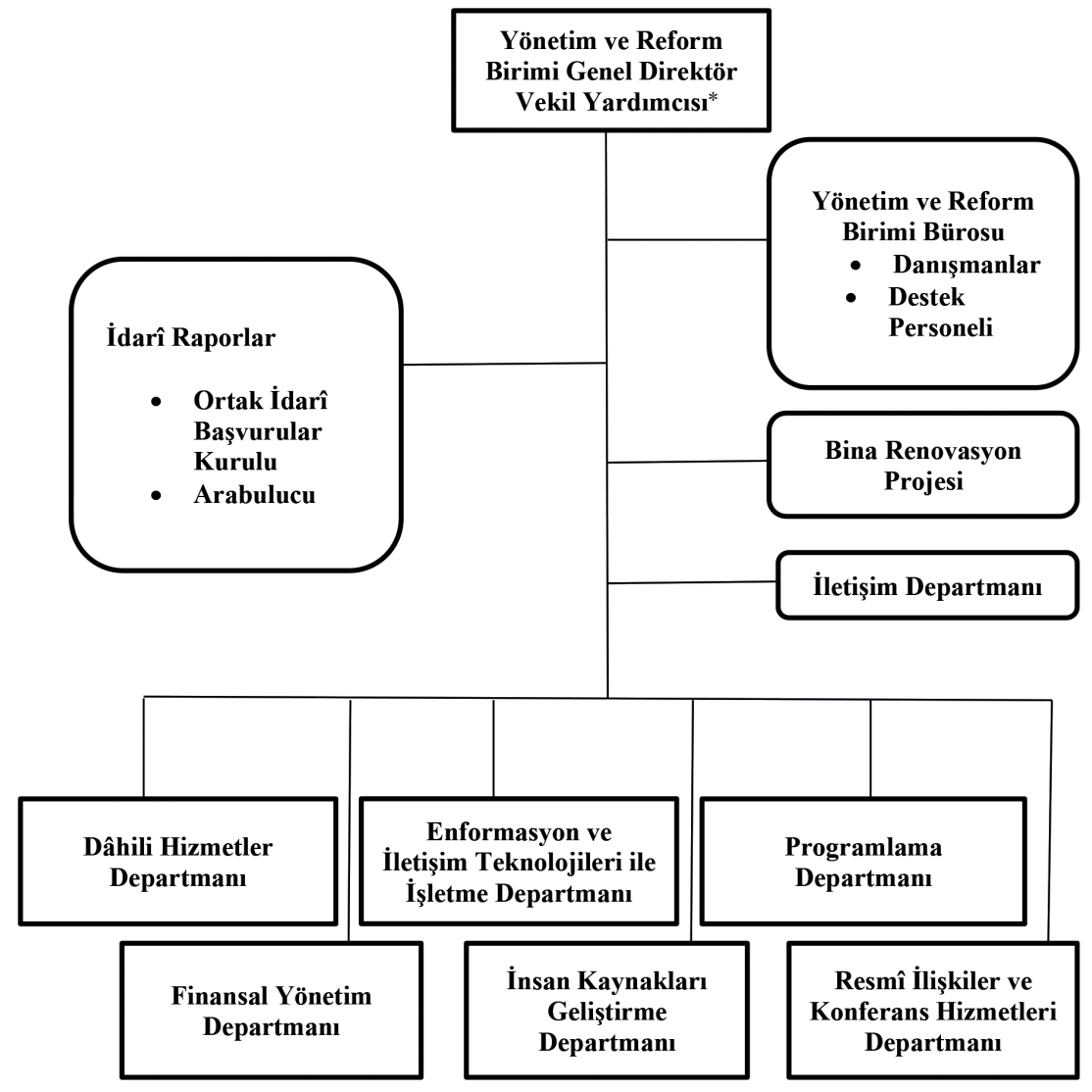

Şekil 5. Yönetim ve Reform Bakanlığg Hiyerarşik Yapılanması

Kaynak: ILO, Reform of the International Labour Organization's Headquarters Organizational Structure (2013). *Deputy Director-General For Management and Reform

Yatay bir örgütsel yapıya sahip olan Yönetim ve Reform Birimi, Uluslararası Çalışma Örgütü'nün yönetimsel ve idarî fonksiyonlarını yerine getiren altı ana departmandan oluşmaktadır. Bu departmanlar fonksiyonel özelliklerine göre 
şöyle sıralanabilir: (i.) Dâhili Hizmetler Departmanı, (ii.) Enformasyon ve İletişim Teknolojileri ile İşletme Departmanı, (iii.) Programlama Departmanı, (iv.) Finansal Yönetim Departmanı, (v.) İnsan Kaynakları Geliştirme Departmanı ile (vi.) Resmî İlişkiler ve Konferans Hizmetleri Departmanı (ILO, 2013, s. 6).

\section{Saha Operasyonları ve Ortaklıklar Birimi}

Uluslararası Çalışma Örgütü'nün bölgesel faaliyetlerinin etkinliğini ve verimliliğini sağlamak, uluslararası düzeyde hizmet kalitesini artırmak ve korumak için kurulan Saha Operasyonları ve Ortaklıklar Birimi, genel merkezlerle bölgeler arasındaki koordinasyonu ve optimal iş ilişkilerinin tesis edilmesini temin etmektedir. Örgütün tüm birimlerinin ve departmanlarının hedeflerine ulaşması ve bu hedefleri geliştirmesi amacıyla uluslararası ortaklıklar kurmak ve projeler üretmek bu birimin görevleri arasında yer almaktadır. Şekil 2'deki Ulusal İnovasyon Ekosistemi'ni uluslararası inovasyon ekosistemine entegre edebilmek için Saha Operasyonları ve Ortaklıklar Birimi çok uluslu küresel bir iktisadî sistemde uluslararası aktörlerle koordinasyon içinde, Birleşmiş Milletler ve diğer örgütlerle işbirliği yaparak ortaklıklar kurmak durumundadır.

Genel Direktör Yardımcısı tarafindan yönetilen Saha Operasyonları ve Ortaklıklar Birimi'nin ana hedefleri beş maddede siralanabilir (ILO, 2013, s. 7).

- Genel merkezlerle bölgeler arasındaki etkileşimde uluslararası entegrasyonu sağlamak ve örgütün bütünlüğünü koruyarak örgüt faaliyetlerini tek bir çatı altında toplamak. Genel merkezlerin programlarıyla bölgelerdeki uygulamalar arasında birlik ve bütünlük oluşturmak. Uluslararası Çalışma Örgütü bu hedefe ulaşmak için daha çok (c) kategorisindeki üçüncü tür enformasyon sistemleri inovasyonunu kullanmaktadır.

- Ar-Ge faaliyetleriyle aynı doğrultuda politika geliştirmek ve teknik koordinasyonu sağlamak yoluyla örgütün çalışma programlarını daha etkin bir şekilde uygulamaya geçirmek. Örgüt bu hedefe ulaşmak için daha çok (a) kategorisindeki üçüncü tür enformasyon sistemleri inovasyonunu kullanmaktadir.

- Yönetim ve Reform Birimi ile yakın bir işbirliği içerisinde saha operasyonlarını doğrudan etkileyen iş süreçlerinin ve prosedürlerinin verimlilik düzeyini artırarak Şekil 3'deki Uluslararası Çalışma Örgütü enformasyon sistemleri akışını kolaylaştırmak. 
- Genel merkezlerdeki iş akışıyla bölgelerdeki ve Torino' da kurulan Uluslararası Eğitim Merkezi arasındaki koordinasyonu artırarak daha güçlü bir sinerjiye ulaşmak. Şekil 2'deki Ulusal İnovasyon Ekosistemi'nin bileşenlerine temel oluşturan 2 numaralı ‘Önerme,' Uluslararası Çalışma Örgütü’nün bu hedefini fonksiyonel olarak ifade etmektedir.

- Kaynak mobilizasyonu potansiyelini maksimize etmek ve ortaklık alanlarıyla çok uluslu ilişkilerdeki iş bölünmesinin üstesinden gelmek için küresel entegrasyonu artıracak enformasyon ve inovasyon sistemlerini örgütün kaynaklarıyla örgüt içindeki karar alıcıların davranışsal tercihlerine uyumlu hâle getirmek.

- Politika Birimi ile yakın işbirliği kurarak çok uluslu küresel sistem içerisinde adil çalışma politikaları geliştirmek. Bu hedef, departmanlar arasındaki yatay ve dikey entegrasyonun sağlanarak enformasyon akışının kolaylaştırılmasını ve inovasyonun kurumlar arasındaki dolaşımının hızlanmasinı gerektirmektedir.

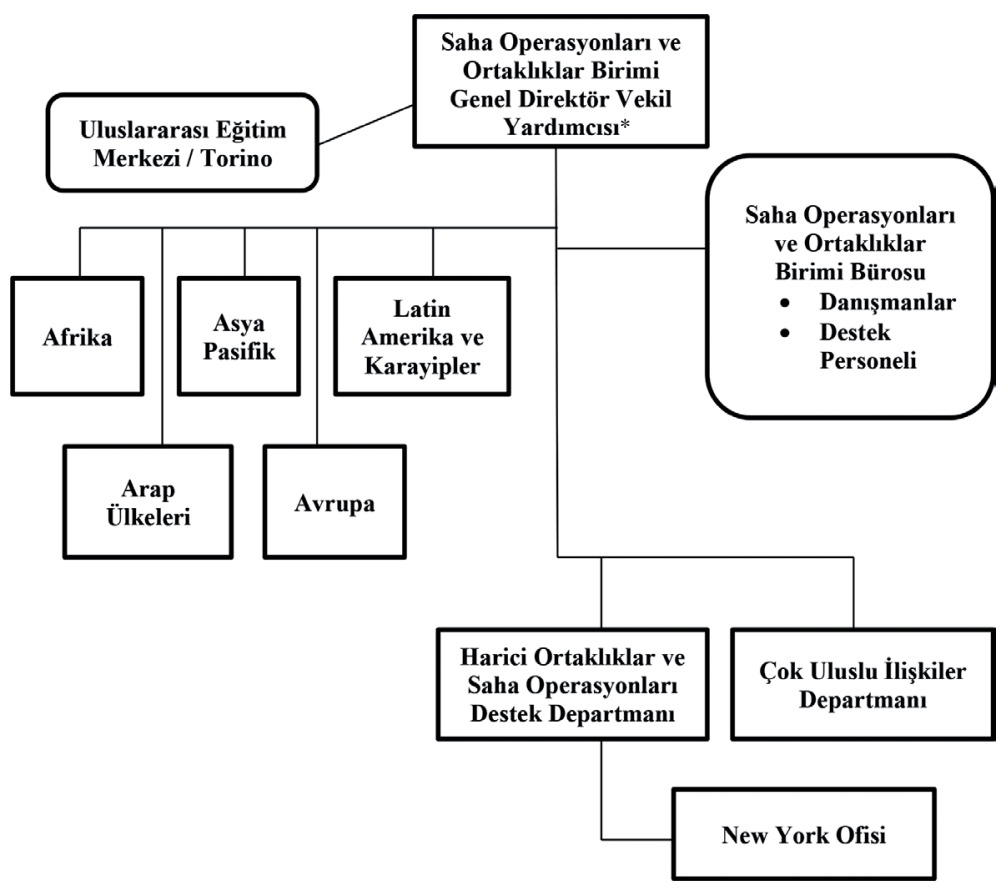

Şekil 6. Saha operasyonları ve ortaklıklar bakanlığı hiyerarşik yapılanması

Kaynak: ILO, Reform of the International Labour Organization's Headquarters Organizational Structure (2013). *Deputy Director-General for Field Operations and Partnerships 
İtalya'nın Torino şehrindeki Uluslararası Eğitim Merkezi ile bağlantılı çalışan Saha Operasyonları ve Ortaklıklar Birimi, Uluslararası Çalışma Örgütü’nün Afrika, Asya Pasifik, Latin Amerika ve Karayipler, Arap Ülkeleri ve Avrupa bölgelerindeki beş kıtada faaliyetlerinin ve programlarının yönetiminden sorumludur. Yapısal reform süreci esnasında revizyon tamamlanana kadar bölgelerdeki birimler mevcut coğrafî yapı temelinde faaliyet göstermeye devam etmektedirler. Diğer birimlerle stratejik işbirliği içerisinde hem yatay hem dikey bir örgütsel yapıya sahip olan Saha Operasyonları ve Ortaklıklar Birimi iki ana departmandan oluşmaktadır. Bunlar sırasıyla; (i.) New York Ofisi ile yakın işbirliği içerisinde olan Harici Ortaklıklar ve Saha Operasyonları Destek Departmanı ile (ii.) Çok Uluslu İlişkiler Departmanı olarak adlandırılmaktadır (ILO, 2013, s. 8).

\section{Uluslararası Çalışma Örgütü Enformasyon Sistemleri}

Uluslararası Çalışma Örgütü’nün birimler nezdindeki reformlarla gerçekleşen yeni yapılanmas1, enformasyon ve inovasyon sistemleri altyapısındaki değişiklikleri ve gelişmeleri de beraberinde getirmiştir. Küresel bir ekonomide enformasyon yönetimi, uluslararası örgütler için stratejik bir öneme sahiptir. Yapak zekâ teknolojisiyle verilerin işlenmesi ve depolanması, enformasyon ve inovasyon yönetiminin etkinliğini ve verimliliğini artırmaktadır. Veritabanı yönetim sistemleri de küresel ekonomideki teknolojik altyapının temelini oluşturmaktadır (Gordon \& Gordon, 1999, s. 118).

Uluslararası Çalışma Örgütü’nün enformasyon sistemleri, konularına, veri türlerine, departmanlara ve birimlere, bilgisayar yazılımlarına ve veritabanı yönetim sistemlerine göre gruplara ayrılmaktadır. Örgütün yapısal reformlar çerçevesinde kurulan birimlerdeki enformasyon sistemlerini üç ana başlık altında inceleyebiliriz. Bunlar; (i.) Politika Birimi Enformasyon Sistemleri, (ii.) Yönetim ve Reform Birimi Enformasyon Sistemleri ile (iii.) Saha Operasyonları ve Ortaklılar Birimi Enformasyon Sistemleri olarak adlandırılmaktadır.

\section{Politika Birimi Enformasyon Sistemleri}

Uluslararası Çalışma Örgütü'nün inovasyon temelli yapısal reformuyla kurulan Politika Birimi'ne bağlı enformasyon sistemleri elli bir alt kategoriye ayrılmıştır (ILO, 10 Haziran 2019). Şekil 4'deki şemada gösterilen yatay bir 
örgütsel hiyerarşik yapılanma içinde her biri fonksiyonel ve stratejik öneme sahip olan bu kategoriler, Politika Bakanlığı'nın yukarıda dört madde altında toplanan ana hedeflerinin gerçekleştirilmesinde ve bu hedeflerin etkin bir biçimde sürdürülmesinde önemli rol oynamaktadır.

- Uluslararası İşgücü Standartları Enformasyonu (“APPLIS”)

- Y1llk Süreli Yayın Koleksiyonu (“ARC”)

- İşgücü Temelli Teknolojiye Dair Bibliyografik Veritabanı (“ASISTDOC”)

- Kamboçya'da Daha İyi Fabrikalar İçin Şeffaflık Veritabanı (“Better Factories”)

- İş Güvenliği ve Sağlığı Veritabanı (“CISDOC”)

- Sosyal Sigorta Maliyeti 1990-96 (“CSS”)

- DEKLARASYON Web sitesi ("DECLARATION")

- İktisadî Olarak Aktif Nüfus 1950-2010 (“EAPEP”)

- İstihdam/İşletme Kaynak Platformu (“EMPENT”)

- İstihdam Güvenliği Yasası Özet Göstergeleri - Düzenli İş Sözleşmelerinin Sonlandirılmasına Dair Veriler ("EPLEX Summary”)

- CINSIYYET Web sitesi (“GENDER”)

- Hanehalk1 Gelir ve Harcama İstatistikleri ("HIES”)

- HIV/AIDS Kanunları ve Politikaları ("HIV/AIDS")

- Uluslararası Çalışma Örgütü Karşılaştırmalı İstihdam ve İşsizlik Tahminleri ("ILOCOMP")

- Uluslararası İşgücü Standartları Veritabanı ("ILOLEX”)

- Uluslararası Çalışma Örgütü İstatistik Veritabanı (“ILOSTAT”)

- Gayri Resmî Sektör İstihdamı ("INFORMAL”)

- Enstitüler ve İrtibatlar Veritabanı ("INSTITUTIONS")

- Çocuk İşgünü Elimine Etme Programı Ülkeleri Kontrol Yönetimi (“IPEC Countries Dashborad") 
- Çocuk İşgücü İstatistiksel Enformasyon ve İzleme Programı ("IPEC SIMPOC Child Labour Statistics")

- Çocuk İşgücünü Elimine Etme Programı Ülkeleri Kontrol Yönetimi Veritabanı ("IPEC Programme Database")

- 2008 Küresel Finansal ve Ekonomik Krizine Karşı Uluslararası Çalışma Örgütü / Dünya Bankası Envanter Politikası Reaksiyonları (“IPRC”)

- Uluslararası Çalışma Örgütü Endüstri İlişkileri Yasal Veritabanı (“IRLEX”)

- İşgücü Piyasası Temel Göstergeleri (“KILM”)

- Uluslararası Çalışma Örgütü İşgücü İstatistikleri Veritabanı (“LABORSTA”)

- İktisadî Olarak Aktif Nüfus ("LABORSTA/1”)

- Mesai Saatleri ve Ücretler ("LABORSTA/3")

- İmalat Sanayisinde İşgücü Maliyetleri (“LABORSTA/4”)

- Tüketici Fiyatları ("LABORSTA/5")

- Meslek Kazaları (“LABORSTA/6”)

- Grevler ve Lokavtlar (“LABORSTA/7”)

- Dernek Özgürlüğü Komitesi Veritabanı (“LibSynd”)

- Asgarî Ücretler (“MINWAGE”)

- Uluslararası Çalışma Örgütü Mikro Veri Deposu ("Microdata Repository”)

- Ulusal İşgücü Yasası Veritabanı (“NATLEX”)

- Uluslararası İşgücü İstatistikleri Enformasyon Sistemi ("NORMLEX”)

- Mesai Saatleri ve Ücretler (Ekim Araştırması) (“OCTINQ/1”)

- Gıda Fiyatları (Ekim Araştırması) (“OCTINQ/2”)

- Meslekî Güvenlik ve Sağlik Ülke Profilleri (“OSH-Country Profiles”)

- Kamu Kesimi İstihdamı ("PUBLIC")

- Mesleklerdeki Cinsiyet Ayrımı (“SEGREGAT”) 
- İstihdam Bilgi Paylaşım Platformu Becerileri (“SKP”)

- Sektörel Ülke Profili (“Sectoral Country Profile”)

- Sosyal Güvenlik Platformu (“GESS”)

- Çalışma Koşulları ve İstihdam Yasası Veritabanı ("TRAVAIL”)

• Çocuk İşgücü Farkındalık Projesi (“UCW”)

- Sendika Üyeliği (“UNIONS”)

- Uluslararası Çalışma Örgütü Toplantılarına Kadınların Katılımı (“WPM”)

- Genç İstihdam Envanteri ("YEI”)

- Genç İstihdam Networkü ("YEN")

- Genç İstihdam Politikası Analizi ("YouthPol eAnalysis")

\section{Yönetim ve Reform Birimi Enformasyon Sistemleri}

Uluslararası Çalışma Örgütü'nün inovasyon temelli yapısal reformuyla kurulan Politika Birimi'nden sonra gelen ikinci birim olan Yönetim ve Reform Birimine bağlı enformasyon sistemleri elli sekiz alt kategoriye ayrılmıştır (ILO, 5 Temmuz 2019). Şekil 5'deki şemada gösterilen yatay bir örgütsel hiyerarşik yapılanma içinde her biri fonksiyonel, lojistik ve stratejik öneme sahip olan bu kategoriler, Yönetim ve Reform Birimi'nin yukarıda beş madde altında toplanan ana hedeflerinin gerçekleştirilmesinde ve bu hedeflerin etkin bir biçimde sürdürülmesinde önemli rol oynamaktadır.

- Görsel İşitsel Dağıtım Platformu (“APD”)

- Yayınların Satışları ve Stok Kontrolü (“ARIES”)

- Menkul Kiymetler (“ASSESTS”)

- Uluslararası İşgücü Konferansı Komiteleri Düzenleme Yönetimi ("Amendments")

- Brio Enformasyon Erişim Portalı ("BRIO-PORTAL”)

- İletişim, Etkinlik Yönetimi ve Basındaki Haberleri Derleme Hizmeti ("CAMPO") 
- Çocuk İşgücü İstatistikleri (“CLS”)

- Uluslararası İşgücü Konferansı Konuşmacıları Endeksi (“COMPTERENDU”)

- Konferans Yönetim Sistemi (“CONFMGMT”)

- Konferans Görevlileri Yönetimi (“CONFSTAFF”)

- Uluslararası Çalışma Örgütü Veri Deposu (“DATAWAREHOUSE”)

- Emanetçi Kütüphane Enformasyon Sistemi (“DEPOLIB”)

- Ofis Evrakları Takibi ("DOCS")

- Elektronik İşe Alım Sistemi (“E-RECRUITMENT”)

- Umumî Depo (“ETAPE”)

- Elektronik Oy Verme Sistemi ("EVS")

- Kadrolu ve Uzman Bordroları ("FGSPAY")

- Uluslararası Çalışma Örgütü Devamlı Veri Tabloları (“FGSTAB”)

- Enformasyon Teknolojileri Alan Envanteri (“FIELDDIT”)

- Finansal Enformasyon Sistemi ("FIS")

- Harici Ofisler İçin Finansal Entegre Sistemler (“FISEXT”)

- Uluslararası Çalışma Örgütü Küresel İş Krizi Gözlemevi (“Global Job Crisis Observatory")

- Bilişim ve İletişim Teknolojileri Yardım Destek Sistemi (“HELPDESK”)

- Sağlık Sigortası Enformasyon Sistemi (“HIIS”)

- İnsan Kaynakları Personel Kişisel Gelişim Programları (“HRPULSE”)

- İnsan Kaynakları IBM Ana Bilgisayar Sistemleri (“HRSYSTEMS”)

- Oracle PL/SQL A ğ Geliştirici Hizmet Programları (“HTTPUTILS”)

- Uluslararası Çalışma Örgütü Kurumsal Web Sitesi (“ILO Public Website”)

- Uluslararası Çalışma Örgütü Sosyal Güvenlik Araştırmaları Veritabanı ("ILOSSI") 
• Uluslararası Çalışma Örgütü Tasnifleri (“ILOTAXO”)

- Uluslararası Çalışma Örgütü Terminoloji Veritabanı ("ILOTERM”)

- Uluslararası Çalışma Örgütü Kavramlar Dizini (“ILOTHES”)

- Uluslararası Çalışma Örgütü İntranet Web Sitesi (“INTRANET”)

- Sipariş İşlemleri (Envanter ve Stok kontrolü) (“INVENT”)

- Enformasyon Sistemleri Envanteri (“ISINVENTORY”)

- Uluslararası Çalışma Örgütü Kütüphanesi Bibliyografik Veritabanı (“LABORDOC")

- İşgücü Araştırmaları Veritabanı (“LFSURVEY”)

- Multimedya Yükleme Merkezi (“MDC”)

- Tibbî Muayene Takip Sistemi (“METS”)

- Uluslararası Çalışma Örgütü Sabit Telefon Yönetim Sistemi (“OMNIVISTA”)

- Uluslararası İşgücü Konferansları Kadrosunun Fazla Mesai Yönetim Sistemi (“OVERTIME”)

- Telefon Ücretleri (“PASTEL”)

- Personel Enformasyon Sistemi ve Arayüzleri ("PERSIS \& Interfaces”)

- Uluslararası Çalışma Örgütü Fotoğraf Arşivi ("PHOTOTEQUE”)

- Çalışma Hakları Yönetim Sistemi ("R2K”)

- Kiralık Sübvansiyon Sistemi ("RENTALSUBS")

- Eser Sahipleri ve Sözleşmeler ("RIT”)

- Denizcilik İşini Bırakanların Kaza Raporlarına Dair Veritabanı (“SEAFARERS")

- Uluslararası Çalışma Örgütü’nün Resmî Yazışmalarının Sicil Kayıtları ("SPHINX")

• Uluslararası Çalışma Örgütü Devamlı Verileri (“STANDINGDATA”) 
- Geniş Kapsamlı Araştırma Formları (“SURVEYFORMS”)

- Bilgisayar Yazılım Lisanları Yönetim Sistemi (“SWLICENCE”)

- Orta Afrika İstihdam Enformasyon Sistemi (“n.a.")

- Eğitim İdare Sistemi (“TRAINING”)

- Gönüllü Tasarruf Fonu ("VTBF”)

- Uluslararası Çalışma Örgüt Sarı Sayfalar ("YELLOWPAGES”)

- Y1l Sonu Listesi - Lokal Kadro ("YELPC")

- Zen Konfigürasyon Yöneticisi (“ZCM”)

\section{Saha Operasyonları ve Ortaklıklar Birimi Enformasyon Sistemleri}

Uluslararası Çalışma Örgütü'nün inovasyon temelli yapısal reformuyla kurulan Politika Birimi ile Yönetim ve Reform Birimi'nden sonra gelen üçüncü birim olan Saha Operasyonları ve Ortaklıklar Birimine bağlı enformasyon sistemleri elli sekiz alt kategoriye ayrılmıştır (ILO, 15 Ağustos 2019). Şekil 6'daki şemada gösterilen yatay ve dikey bir örgütsel hiyerarşik yapılanma içinde her biri fonksiyonel, lojistik, stratejik ve coğrafik öneme sahip olan bu kategoriler, Saha Operasyonları ve Ortaklıklar Birimi'nin yukarıda beş madde altında toplanan ana hedeflerinin gerçekleştirilmesinde ve bu hedeflerin etkin bir biçimde sürdürülmesinde önemli rol oynamaktadır.

- İngilizce ve Hollandaca Konuşan Karayipler'deki Uluslararası Çalışma Örgütü’ne Üye Ülkelerin İşgücü Yasası Veritabanı (“CARIBLEX”)

- Sosyal Güvenlik Enformasyon Merkezi (“CIPS”)

- Uluslararası Çalışma Örgütü Genelgeleri (“CIRCULARS”)

- Karayipler İşgücü Piyasası Veritabanı (“CLMD”)

- Standartların Düzenli Kontrolü (“Corenit”)

- Bağış Kontrol Paneli (“DDB”)

- İstihdam ve İşsizlik (“LABORSTA/2")

- Latin Amerika Bölgesel Portalı (“LAT-PORTAL-WCMS”) 
- Orta ve Doğu Avrupa'da İş Güvenliği, Sağlık ve Çevre (“OSH IN EAST EUROPE")

- Proje Enformasyonu Listeleme Sistemi (“PILS”)

- Latin Amerika ve Karayipler İşgücü Enformasyon Sistemi (“QUIPUSTAT”)

- Kontrat Sistemleri (“SCONTRACT”)

- Küçük İşletmeler Veritabanı (“SED”)

- Bölgesel Programlama Sistemleri (“SPROGRAM”)

- Birim Hedefleri Veritabanı 2002-3 (“UNITOBJECTIVES”)

- İyi Yönetilen Dış İlişkiler Enformasyon Sistemi ("WHERE”)

Uluslararası Çalışma Örgütü’nün resmî web sitesinde yer alan enformasyon sistemleri kontrol panelinde sıralanan bu kategorilerin arayüz kodları makalemizde parantez içinde ve çift tırnak işareti ile gösterilmektedir. Fakat kontrol panelinde aktif link şeklindeki kodlar tıklandığında güvenlik duvarı engeliyle karşılaşılmakta ve ilgili veri tabanına dışarıdan erişim sağlanamamaktadır. Uluslararası Çalışma Örgütü'nün enformasyon sistemleri idarî uygulamalar dâhilinde tasarlandıkları için açık erişime kapalıdır (ILO, 20 Ağustos 2019).

\section{Sonuç}

Uluslararası Çalışma Örgütü'nün inovasyon temelli yapısal reformlar yoluyla hiyerarşik altyapısını enformasyon sistemleri ile sağlamlaştırması küresel ekonominin değişen koşulları karşısında bir gereklilik olarak gerçekleşmiştir. Soğuk Savaş ekonomisinin ardından küresel dengelerin değişmesinden dolayı yeni bir paradigma inovasyonuyla yapısal dönüşüm geçiren piyasa ekonomileri giderek daha fazla entegre bir küresel ve dijital sisteme doğru gelişme göstermişlerdir. 1919 yılında Birleşmiş Milletler'in bir ihtisas kuruluşu olarak faaliyetlerine başlayan Uluslararası Çalışma Örgütü'nün sosyal adaletin sağlanması, işçilerin hak ve menfaatlerinin korunması yönündeki ana hedeflerinin yanı sıra küresel iktisadî aktörlerin ve piyasa dinamiklerinin karşılıklı etkileşim içerisinde oldukları stratejik hedefleri de vardır.

Hükümetlerarası bir kuruluş olan Uluslararası Çalışma Örgütü, faaliyetlerini hükümet-işçi-işveren temsilcilerinden oluşan ve 'Tripartizm' adı verilen üçlü 
bir stratejik yapı içerisinde uluslararası düzeyde sürdürmektedir. Örgütün dört temel stratejik hedefi (i.) uluslararası çalışma koşullarını kanun yoluyla temel prensipler ve haklar temelinde iyileştirerek işçilerin hayat standartlarını yükseltmek; (ii.) daha insancıl çalışma koşulları altında kadınlar ve erkekler arasında firsat eşitliği sağlamak, (iii.) sosyal sigorta ve iş güvenliği konularında temel hakların kapsamını ve uygulama alanlarını genişleterek küresel sistem içinde daha etkin politikalar üretmek; (iv.) Tripartizmi ve sosyal diyaloğu güçlendirerek işçilerin haklarını korumak olarak sıralanabilir.

$\mathrm{Bu}$ dört stratejik hedef, örgütün faaliyet prensipleriyle bir bütünlük göstermektedir. 21. yüzyılda Uluslararası Çalışma Örgütü kurumsal yapısında gerçekleştirdiği reformlarla faaliyet prensiplerine uygun stratejik hedeflere ulaşmada daha fazla dinamizm kazanmıştır. Hükümet-işçi-işveren temsilcilerinden oluşan 'Tripartizm,' Şekil 4'deki Politika Birimi hiyerarşik yapılanması içerisinde Yönetim ve Tripartizm Departmanı'nın kurulmasıyla resmî bir platform kazanmıştır. Böylelikle sosyal diyaloğun sağlanması ve sürdürülmesi, küresel sisteme entegre olabilen sağlam bir enformasyon sistemi altyapısıyla olanaklı duruma gelmiştir. Benzer şekilde, aynı yatay hiyerarşide diğer departmanlarla stratejik bir etkileşim içinde yer alan İstihdam Politikası Departmanı, örgütün stratejik hedeflerini gerçekleştirme yolunda sürdürülebilir büyüme için sürdürülebilir istihdam anlayışılla küresel anlamda inovasyon temelli kapsayıcı bir istihdam politikasına önem vermektedir.

Politika Birimi’ndeki İstihdam Politikası Departmanı'nın reform yoluyla yeniden düzenlenen altyapısı farklı birimlerin bağlı olduğu çeşitli kategorilerdeki enformasyon sistemleri ile desteklenmektedir. İstihdam Politikası Departmanı bünyesinde Entegrasyon Birimi (INTEGRATION), İstihdam ve Politika Birimi (EMP/POL), Uluslararası Çalışma Örgütü Kriz Birimi (ILO/CRISIS), İstihdam, İktisat ve İşgücü Piyasası Analizi Birimi (EMP/ELM), İstihdam Becerileri Birimi (EMP/SKILLS), İstihdam ve Yatırım Birimi (EMP/INVEST), Eğitim, İstihdam ve Yönetim Destek Birimi (ED/EMP/MSU) ile Genç İstihdam Programı yer almaktadır. Bu birimlerin her biri Uluslararası Çalışma Örgütü’nün Enformasyon Sistemleri'ne bağlıdır. Entegrasyon Birimi altyapısında yer alan enformasyon sistemleri üç alt kategoride toplanmaktadır. (i.) Yoksulluk, Bölgesel Kalkınma ve Adil İş Kaynakları Veri Tabanı ("DWRESOURCES”), (ii.) Fikir Bankası ("IDEASBANK”), (iii.) Gayri Resmî Ekonomi Kaynak Veri Tabanı ("IERESOURCES"). 
10 Haziran 2008 tarihinde Cenova' da gerçekleştirilen Uluslararası İşgücü Konferansı'nda imzalanan Adil Küreselleşme İçin Sosyal Adalet Deklarasyonu ile yürürlüğe giren yapısal reformlar sayesinde yeni birimlerin kurulmasıyla Uluslararası Çalışma Örgütü' nün hiyerarşik yapılanmasındaki departmanlar ve birimler inovasyon temelli enformasyon sistemleriyle örülü karmaşık ve güçlü bir altyapı ağına kavuşmuştur. Bu reformlar örgütün küresel ekonomiler arasındaki entegrasyonun sağlanmasındaki rolünü daha da artırmış ve piyasaların eksik istihdam düzeyinde kalmasına neden olan Keynezyen koordinasyon hatalarını da büyük ölçüde telâfi ederek ortadan kaldırmıştır. Uluslararası Çalışma Örgütü kuruluş amaçlarına ve prensiplerine uygun olarak bünyesindeki birimler nezdinde gerçekleştirdiği bir dizi yapısal reformla hızla dijitalleşen küresel iktisadî sistemdeki otoritesini ve itibarını korumayı başarmıştır.

Finansal Destek: Yazar bu çalışma için finansal destek almamıştır. 


\section{Kaynakça/References}

Allen, b. (1982). some stochastic processes of interdependent demand and technological diffusion of an innovation exhibiting externalities among adopters. International Economic Review, 23(3), 595-608.

Becker, S. W., \& Whisler, T. L. (1967). The innovative organization: A selective view of current theory and research. Journal of Business, 40, 462-469.

Buitendam, A., \& Pennings, J. M. (Ed.). (1987). New Technology as Organizational Innovation: The Development and Diffusion of Microelectronics. Ballinger Publishing Company.

Chandler, A. D. (1977). The visible hand: The managerial revolution in American business. Cambridge, MA, Harvard University Press, 51, 107-108.

Child, J. (1987). Information technology, organization, and the response to strategic challenges. California Management Review, 30(1), 33-50.

Council on Competitiveness. (2004). 21 st Century Innovation Working Group. Innovation, The New Reality for National Prosperity, Council on Competitiveness, Washington, DC.

Daft, R. L. (1978). A dual-core model of organizational innovation. Academy of Management Journal, 21(2), 193-210.

Daft, R. L. (1982). Bureaucratic versus nonbureaucratic structure and the process of innovation and change. Research in the Sociology of Organizations, 1(1), 129-166.

Damanpour, F. (1991). Organizational innovation: A meta-analysis of effects of determinants and moderators. Academy of Management Journal, 34(3), 555-591.

Gordon, J. R., \& Gordon, S. R. (1999). Information Systems: A Management Approach. America: Dryden Press.

Watanabe, C., \& Fukuda, K. (2005). National Innovation Ecosystems: The Similarity and Disparity of Japan-US Technology Policy Systems toward a Service-Oriented Economy. International Institute for Applied Systems Analysis, Laxenburg, Austria.

ILO. (2008). The Declaration on Social Justice for a Fair Globalization, ILO.

ILO. (2013). Reform of the International Labour Organization's Headquarters Organizational Structure, ILO.

ILO. (10 Haziran 2019). Policy Portfolio Information Systems, Erişim Tarihi: 10 Haziran 2019, https://www.ilo.org/dyn/isinventory/inventsheet.list?p searchkey $=20190821171531 \&$ p_lang $=$ en.

ILO. (5 Temmuz 2019). Management and Reform Portfolio Information Systems, Erişim Tarihi: 5 Temmuz 2019, https://www.ilo.org/dyn/isinventory/inventsheet.list?p searchkey $=20190821172240 \& p \_l a n g=e n$

ILO. (15 Ağustos 2019). Field Operations and Partnerships Portfolio Information Systems, Erişim Tarihi: 15 Ağustos 2019, https://www.ilo.org/dyn/isinventory/ inventsheet.list?p_searchkey $=20190821172557 \&$ p_lang $=e n$ 
ILO. (20 Ağustos 2019). ILO Information Systems, Erişim Tarihi: 20 Ağustos 2019, https://www.ilo.org/dyn/isinventory/inventsheet.search.

Jalonen, H. (2012). The uncertainty of innovation: A systematic review of the literature. Journal of Management Research, 4(1), 1.

Krugman, P. (1979). A model of innovation, technology transfer, and the world distribution of income. Journal of Political Economy, 87(2), 253-266.

Lawrence, P. R., \& J. W. Lorsch. (1967). Organization and environment: Managing differentiation and integration. Cambridge, MA: Harvard University Press.

Maupain, F. (2009). New foundation or new façade? The ilo and the 2008 declaration on social justice for a fair globalization. European Journal of International Law, 20(3), 823-852.

O’Connor, G. C. (2012). Innovation: From process to function. Journal of Product Innovation Management, 29(3), 361-363.

Porter, M. E. (1988). Information Hierarchies. Symposium on Increasing Business Competitiveness Through Management Information Systems, Academy of Management Annual Meeting, Anaheim, CA.

Rogers, E. M. (1983). Difusion of Innovations. New York: The Free Press.

Sorensen, O., \& L. Fleming. (2004). Science and the diffusion of knowledge. Research Policy, 33, 1615-34.

Stigler, G. J. (1951). The division of labor is limited by the extent of the market. Journal of Political Economy, 59(3), 185-193.

Swanson, E. B. (1994). Information systems innovation among organizations. Management Science, 40(9), 1069-1092.

Tornatzky, L., \& Fleischer, M. (1990). The process of technology innovation. Lexington, MA: Lexington Books.

Vagnani, G., Gatti, C., \& Proietti, L. (2019). A conceptual framework of the adoption of innovations in organizations: A meta-analytical review of the literature. Journal of Management and Governance, 1-40.

Weigel, F. K., Hazen, B. T., Cegielski, C. G., \& Hall, D. J. (2014). Difusion of innovations and the theory of planned behavior in information systems research: A meta-analysis. Communications of the Association for Information Systems, 34(1), 31-43.

Zaltman, G., Duncan, R., \& Holbek, J. (1973). Innovations and organizations. New York: Wiley. 